\title{
The Practice of Presidential Succession in Indonesia
}

\author{
Dian Aries Mujiburohman* \\ DOI: https://doi.org/10.22304/pjih.v7n2.a6
}

Submitted: July 21, 2020 | Accepted: August 31, 2020

\begin{abstract}
This study analyzed Article 8 of the 1945 Constitution of the Republic of Indonesia on the presidential succession in Indonesia. The 1945 Constitution clearly regulates presidential and vice-presidential election period for once in five years. However, the practice of presidential succession can be unpredictable. This article aims to elaborate the management of presidential succession in Indonesia. The study in this article employed normative research method by applying a statute approach. The finding of the study proves that based on Article 8 of the 1945 Constitution; there are four circumstances of presidential substitutions. They are decease, resignation, dismissal, and inability to carry out duties. However, in the actual practices that have been happened several times, the presidential successions in Indonesia were not always caused by the four conditions. The examples are the successions of Soekarno, Soeharto, and Abdurrahman Wahid. The three Presidents were dismissed without transparent legal reasons. Their dismissals were based merely on political decisions, not legal reasons. In addition, political transitions, internal conflicts, and economic crises contributed to the presidential successions in Indonesia.
\end{abstract}

Keywords: presidential succession, the office of president, 1945 Constitution of the Republic of Indonesia.

\section{Praktik Pergantian Jabatan Presiden di Indonesia}

\begin{abstract}
Abstrak
Artikel ini menganalisis Pasal 8 Undang-Undang Dasar Negara Republik Indonesia (UUD NRI 1945) terkait dengan pergantian presiden di Indonesia. Pengaturan mengenai pemilihan presiden dan wakil presiden dalam undang-undang dasar sudah jelas kapan waktunya, yaitu lima tahun sekali. Akan tetapi, pergantian presiden merupakan peristiwa yang tidak dapat diprediksi kapan akan terjadi. Artikel ini bertujuan untuk menelaah bagaimana sesungguhnya sistem pemerintahan Indonesia mengatur pergantian presiden. Temuan ini membuktikan bahwa sesuai dengan Pasal 8 UUD NRI 1945 terdapat empat peristiwa pergantian presiden, yaitu mangkat, berhenti, diberhentikan dan tidak dapat melakukan kewajibannya. Namun, dalam praktek keempat peristiwa pergantian presiden tersebut tidak benar-benar diterapkan sebagaimana pergantian presiden yang terjadi pada masa pemerintahan Presiden Soekarno, Soeharto dan Abdurrahman Wahid. Ketiga presiden tersebut mengalami pergantian presiden tanpa alasan hukum yang jelas, semata-mata
\end{abstract}

PADJADJARAN Journal of Law Volume 7 Number 2 Year 2020 [ISSN 2460-1543] [e-ISSN 2442-9325]

A Lecturer of the National Land College (Sekolah Tinggi Pertanahan Nasional), Jl. Tata Bumi No. 5 Banyuraden, Yogyakarta, S.Pd.I. (Universitas Islam Negeri Sultan Syarif Kasim Pekanbaru), S.H. (Sekolah Tinggi Ilmu HukumIBLAM), M.H. (Universitas Indonesia), esamujiburohman@stpn.ac.id 
didasarkan atas keputusan politik ketimbang alasan-alasan hukum. Selain itu, transisi politik, pergolakan dalam negeri dan krisis ekonomi ikut mengiringi pergantian presiden di Indonesia.

Kata kunci: jabatan presiden, pergantian presiden, Undang-Undang Dasar 1945.

\section{A. Introduction}

One of the important issues in the system of constitutional law is the turn of presidency. Presidential succession is a natural process that occurs in every state that implements a republican system. ${ }^{1}$ Duguit explains about this. If a head of state is appointed based on inheritance rights or a hereditary succession order, the state is in the form of a monarchy and the head of the state is called a king. If a head of state is appointed by election, the state is a republic and the head of the state is called a president. ${ }^{2}$ Therefore, the office of president is the single highest office in a republic.

Article 7 of the 1945 Constitution of the Republic of Indonesia regulates the presidential election to be conducted once in five years. The period is obvious but presidential substitution is a rare and unpredictable event. In general, the office of president always moves from a person to another person in a chain of succession, either by natural or other causes. For example, a president may end term of office, be passed away, be dismissed, resign, or suffer health problems. In the practices of state administration, Indonesia had experienced presidential successions before the end of the terms, for instances the successions of Soekarno to Suharto, Soeharto to B.J. Habibie, and Abdurrahman Wahid to Megawati Soekarno Putri.

The office of President is essential. Therefore, it needs to be regulated in the 1945 Constitution as the highest legal authority, balancing the office of President as the highest office in Indonesia. The Indonesian President is the head of the state and the head of the government. Schwartz considers the office of president as "the most powerful elective position in the world". He, therefore, expresses the importance of the office of president. In addition, Supomo says that the representative of people's sovereignty lies on the office of President, not the House of Representatives. He expects a very strong position of the president. ${ }^{3}$

The structure of the 1945 Constitution provides a dominant regulation for the office or the institution of president. A number of articles directly regulates the office of president (e.g. Article 4 to Article 17 and Article 22); and the authorities that provide a strong position to the institution of president. In addition, other

Mohammad Mahfud MD., Membangun Politik Hukum, Menegakkan Konstitusi, Jakarta: Rajawali Press, 2010, pp. 72-73.

2 Muchyar Yara, Pengisian Jabatan Presiden dan Wakil Presiden di Indonesia: Suatu Tinjauan Sejarah Hukum Tata Negara, Jakarta: Nahdilah Ceria Indonesia, 1995, p. 18.

3 Harun Al Rasyid, Pemilihan Presiden dan Penggantian Presiden dalam Hukum Positif Indonesia, Jakarta: Fakultas Hukum Universitas Indonesia, 1995, p. 2. 
provisions cannot be separated from the office of president, such as the provisions on the state budget, the authorities of state institutions, organic law, etc. ${ }^{4}$

The events that are the foundations of presidential succession are regulated in Article 8 (1) of the Third Amendment to the 1945 Constitution. The Article states that "In the event that the President dies, resigns, is impeached, or is not capable of implementing his/her obligations during his/her term, he/she will be replaced by the Vice-President until the end of his/her term". In the next paragraph, Article 8 (2) states that "In the event that the position of Vice-President is vacant, the People's Consultative Assembly should hold a session within sixty days at the latest to elect a Vice-President from two candidates nominated by the President".

Further arrangements are regulated in the Decree of the People's Consultative Assembly (MPR-Majelis Permusyawaratan Rakyat) Number VII/MPR/1973 on the Situation of Incapability of President and/or Vice President of the Republic of Indonesia. Article 2 (1) of the Decree states that in the permanent incapability of the President, he/she will be replaced by the Vice President until the end of his/her term of office. Article 3 (1) states that in the moment that the President is temporarily absent, the President assigns the Vice President to execute the obligations of the President. Then, Article 3 (2) asserts that in the case mentioned in paragraph (1), in the absence of the Vice President, the President appoints a minister to execute the obligations of the Vice President.

Based on the provision of Article 8 (1) of the 1945 Constitution, there are four circumstances of presidential succession. The first is decease. It causes any legal action of termination is not needed. The second is resignation. It has two definitions: (1) by his/her own willingness; and (2) by proposal. Resignation, like in the case of President Soeharto, is in the first definition. The third is impeachment. It means giving up the office at the will of the authorized institution. The example of impeachment by the authorized institution is the case of President Abdurrahman Wahid, who was impeached by the People's Consultative Assembly, which took the policy to exercise replacement as the mean of succession. The fourth is incapability to carry out his/her obligations. It means that the President is either permanently or temporarily unavailable. A president may be incapable because of illness, disappearance without a trace, or others that generate a conclusion of the President incapability. This happened in the case of President Soekarno.

On the other hand, the provisions that regulate the presidential succession are not only found in Article 8 of the 1945 Constitution. It also stated in the Decree of the People's Consultative Assembly. Potentially, it can raise polemics and various interpretations of the constitutional practice as presented in the table.

$4 \quad$ Bagir Manan, Lembaga Kepresidenan, $2^{\text {nd }}$ ed., Yogyakarta: FH UII Press, 2003, pp. 29-30. 
Table 1

The Basis and Reasons for the Indonesian Presidential Succession

\begin{tabular}{|l|l|}
\hline \multicolumn{1}{|c|}{ Legal Basis } & \multicolumn{1}{|c|}{ Reasons for Presidential Succession } \\
\hline $\begin{array}{l}\text { The Decree of the People's } \\
\text { Consultative Assembly Number } \\
\text { VII/MPR/1973 }\end{array}$ & (permanent and temporary) incapability \\
\hline $\begin{array}{l}\text { The Decree of the People's } \\
\text { Consultative Assembly Number } \\
\text { III/MPR/1978 }\end{array}$ & $\begin{array}{l}\text { By his/her own request, permanent } \\
\text { incapability, serious violation on the National } \\
\text { Guidelines of State Policy }\end{array}$ \\
\hline The original 1945 Constitution & $\begin{array}{l}\text { Decease, resignation, or incapability to carry } \\
\text { out his/her obligations }\end{array}$ \\
\hline $\begin{array}{l}\text { The amendment 1945 } \\
\text { Constitution }\end{array}$ & $\begin{array}{l}\text { Decease, resignation, or incapability to carry } \\
\text { out his/her obligations }\end{array}$ \\
\hline
\end{tabular}

The presence of two regulations, one in the 1945 Constitution and the other in the Decree of the People's Consultative Assembly, leads to law degradation. In this case, a subject that has been regulated in the Constitution is deregulated in a lower regulation. According to the legal phrase lex superior derogat legi inferiori, the Decree are ruled out by the 1945 Constitution as the highest regulation. ${ }^{5}$ In the practices of presidential succession, Article 8 of the 1945 Constitution was not implemented completely. The successions were based on political decisions rather than legal reasons. Therefore, this study is to analyze the Article 8 as the foundation of the presidential succession. The proposed question of the study covers the management of presidential succession by the Indonesian government system.

\section{B. Presidential Succession}

\section{The Presidential Succession of Soekarno}

Soekarno is the first President of the Republic of Indonesia following a recommendation from Otto Iskandardinata. ${ }^{6}$ For the first time, the Preparatory Committee for Indonesian Independence elected the president on August 18, 1945, based on the Transitional Provision, Clause III, of the 1945 Constitution stating the Committee's authority to elect the president and the vice president. On the other hand, Article 6 (2) of the 1945 Constitution regulates that it is the authority of the People's Consultative Assembly. In fact, the Assembly had not been established during the initial establishment of the 1945 Constitution.

As a matter of fact, the establishment of the People's Consultative Assembly, which is ordered by the Transitional Provisions, was never been implemented due 
to Dutch Military Aggression and some internal domestic crises. For instance, there was the rebellion of the Indonesian Communist Party (PKI) in Madiun that was subsequently followed by a series of changes from the 1945 Constitution to the 1949 Federal Constitution of the United States of Indonesia to Provisional Constitution of 1950 before then reintroduction of the 1945 Constitution. $^{7}$ Furthermore, until the succession of Soekarno to Soeharto, Article 6 (2) of the 1945 Constitution could not be implemented. The first presidential and vice-presidential election was held in 1973 (28 years later) resulting President Suharto's second term and appointment of the Vice President Sri Sultan Hamengku Buwono IX.

The succession of President Soekarno is inseparable from the event of the Thirtieth of September Movement that involves the Communists, the PKI. Soekarno was accused of carrying out policies that indirectly benefited and protected the Movement's leaders. In addition, economic downturn and moral degradation also made the People's Representative Council of Mutual Assistance (the legislative body at that time) issued a memorandum to the Provisional People's Consultative Assembly asking for President Soekarno's accountability.

President Soekarno responded to the national political and economic conditions. He delivered an accountability report to the Provisional People's Consultative Assembly. His speech is famously known with the title Nawaksara. The Provisional People's Consultative Assembly was dissatisfied with President Soekarno's speech at that time, especially in responding to the related to the Thirtieth of September Movement, the economic downturn, and moral degradation. The Assembly asked President Soekarno to revised and to complete the Nawaksara. President Soekarno fulfilled the demand and subsequently made the Supplement of Nawaksara. However, the accountability speech was also not accepted by the Assembly. Therefore, the Decree of the Provisional People's Consultative Assembly Number XXXIII/MPRS/1967 terminated Soekarno's presidency and appointed Suharto the Acting President.

The decree is the basis of the succession. It revokes the powers of President Sukarno. Article 4 of the Decree emphasizes the statement of the Decree of the Provisional People's Consultative Assembly No. XV/MPRS/1966. It appoints General Soeharto, the Bearer of the Decree Number IX/MPRS/1966, as an Acting President based on Article 8 of the 1945 Constitution until the incoming presidential election by the new People's Consultative Assembly resulted from the succeeding General Election.

The presidential transition from Soekarno to Soeharto is based on Article 8 of the 1945 Constitution. It is not because of Sukarno's decease or resignation but of the conditions that made Soekarno's considered incapable to carry out his 
obligations. ${ }^{8}$ Neither decease nor resignation can be any one of considerations since Soekarno was still alive and never submitted a resignation. The incapability to carry out his obligations was the only reason that was suitable for the succession. ${ }^{9}$ On February 20, 1967, President Soekarno declared devolution of authority to Soeharto before the issue of the Decree of the People's Consultative Assembly Number XXXIII/MPRS/1967. It proves that Soekarno was no longer capable to carry out his obligations.

Manan states that a president may not be capable to carry out his/her obligations during his/her term of office due to several possibilities. Firstly, the president intentionally lefts his/her office environment due to a certain political or legal event that he/she would not retaking office or would be unwanted to take office. Secondly, in certain circumstances, the president, either by his/her own willingness or not, is in a situation that does not allow him/her to carry out his/her obligations. Thirdly, it is not possible, either physically or mentally, for the president to carry out his/her obligations. ${ }^{10}$

The foundation of presidential succession due to decease, resignation, or incapability during term of office, as mentioned in Article 8 of the 1945 Constitution, is categorized as permanently incapable. ${ }^{11}$ In a condition, where president is permanently incapable, the vice president substitutes him/her until the end of term of office. Then, if the president is temporarily unable, he/she assigns the vice president to exercise presidential obligations in a term of assignment determined by the president.

Based on the same article, Soeharto was appointed as the Acting President, so that the office of president is not vacant even for a very short time. ${ }^{12}$ In accordance with Article 8 of the 1945 Constitution, the one that can be appointed president is vice president. However, the provision could not be applied since, at that time, the office of vice president was vacant. Previously, Mohammad Hatta held the office before he resigned on December 1, 1966. Therefore, the office of president was assigned to the bearer of the Order of Eleventh March, Lieutenant General Soeharto. The Order of Eleventh March is a document that was signed by President Sukarno on March 11, 1966. The order gave the army commander Lt. Gen. Suharto authority to take whatever measures he "deemed necessary" to

$8 \quad$ Winarno Yudho, et.al, Seri Penelitian IImiah Mahkamah Konstitusi: Mekanisme Impeachment dan Hukum Acara Mahkamah Konstitusi, Jakarta: Pusat Penelitian dan Pengkajian Sekretariat Jendral dan Kepaniteraan Mahkamah Konstitusi RI, 2005, p. 53.

$9 \quad$ Harun Al Rasyid, Pemilihan Presiden dan Penggantian Presiden dalam Hukum Positif Indonesia, op.cit., pp. 1011.

10 Bagir Manan, Lembaga Kepresidenan, op. cit., pp. 99-100.

11 The Decree of the People's Consultative Assembly Number VII/MPR/1973 on the Situation of Incapability of President and/or Vice President of the Republic of Indonesia.

12 A position in a working environment must continually exist, and a position as a person must continually be represented, see H.A Logeman, Tentang Teori Suatu Hukum Tata Negara Positif (Over de Theorie van Een Stelling Staatsrecht) translated by Makkatutu and J.C. Pangkerego, Jakarta: Ichtiar Baru Van Hoeve, 1975, p. 118. 
restore order to the chaotic situation following the failed Thirtieth of September Movement.

The office of vice president, at that time, was deemed unimportant. It was stated in the Decree of the Provisional People's Consultative Assembly Number XV/MPRS/1966 on the Election or the Appointment of The Vice President and the Procedures on the Appointment of the Office of President. The Decree states that the People's Consultative Assembly did not appoint a vice president. If the President was incapable, the bearer of the Order of Eleventh March exercised the office of president. Based on Article 8 of the 1945 Constitution, the People's Consultative Assembly immediately elected a president who would hold office until the new People's Consultative Assembly had been formed after a general election.

\section{The Presidential Succession of Soeharto}

President Soeharto resigned on May 21, 1998, after holding the office for 32 years, started from receiving the mandate of the Order of Eleventh March. His decision was a response to the massive students' demonstrations and public pressure due to the economic crisis. The economic crisis led to political crisis and massive demonstrations demanding reforms in all matters of national and state life. The situation eventually accelerated the resignation of Soeharto's.

The process has raised legal debates after Soeharto's statement that more or less mentioned his termination as the President of the Republic of Indonesia "after I read this statement, today, Thursday, May 21 1998". The pros and cons were on whether Soeharto was resigned; or he declared his presidential termination. Each condition causes legal consequences. A statement of resignation, based on the Constitution, requires a mechanism for a Special Session in the People's Consultative Assembly to decide whether the Assembly accepts or rejects the resignation. In the meantime, it was not possible to hold a session in the building of the People's Consultative Assembly because demonstrators were occupying the building. On the other hand, a termination is a unilateral statement. The President could terminate his office without having to attend Special Session to request the Assembly's approval.

In fact, both termination and resignation have legal basis respectively. Termination is mentioned in Article 8 of the 1945 Constitution; and resignation is mentioned in Article 4 of the Decree of the People's Consultative Assembly Number III/MPR/1978 on the Position and the Work-Order Relationship of the Highest State Institution with/or Among State Higher Institutions. It explains the reasons for any termination before the term of office ends. It can be due to president's own request, incapability, or serious violation on the National Guidelines of State Policy.

In the termination of Soeharto's presidential office, according to Article 8 of the 1945 Constitution, B.J. Habibie, as the vice president, appointed the president. Then, B.J. Habibie took the oath of office before the Chief Justice of the Supreme 
Court. However, the presidential oath of office before the Supreme Court triggered other debates among the law practitioners. Some parties considered appointment of Habibie unconstitutional because it violated Article 9 of the 1945 Constitution. The article requires the oath of office to be performed before the People's Consultative Assembly and the House of Representatives. The reason behind the opinion is that it is in line with Article 6 (2) that the People's Consultative Assembly, by the most votes, elect's president and vice president. Therefore, the only legal action left is to take an oath of office.

On the other hand, the presidential oath of office before the Supreme Court can be considered constitutional since Article 2 (3) of the Decree of the People's Consultative Assembly Number VII/MPR/1973 on the Situation of Incapability of President and/or Vice President of the Republic of Indonesia. The decree regulates that if the House of Representatives is unable to hold a meeting, the vice president takes an oath of office or a promise before the Supreme Court in advance to hold the office of president. Therefore, it is not necessary to hold the Special Session, which requires a high budget.

Habibie became the President after taking the oath of office on May 21, 1998, up to October 19,1999 . His term of office, which originally should end in 2003 , was relatively short due to his willingness to accelerate the General Election. Therefore, the expression "until the end of the term" in Article 8 of the 1945 Constitution was not implemented. The vacant position of the vice president was not filled after Habibie's appointment.

Previously, the role of vice president in the Indonesian government system does not wield day-to-day political power. A vice president is only a person whose primary responsibility is to act in place of the president on the event of the president's death, resignation, or incapacity. ${ }^{13}$ According to Al Rasyid, role of vice president is only to assist president in carrying out daily tasks, to represent president, and to fill the vacant office of president. ${ }^{14}$ During the term of President Soekarno, the office of vice president was left vacant after the resignation of Hatta on December 1, 1966. The position was vacant up until the appointment of Sri Sultan Hamengkubuwono IX as the vice president of President Soeharto on March 24, 1973. During the term of President Soeharto, there were only vice-presidential successions, not presidential succession of course. Soeharto's vice presidents were Sri Sultan Hamengkubuwono IX, Adam Malik, Umar Wirahadikusumah, Sudharmono, Try Sutrisno, and B.J Habibie.

\section{The Succession of President Abdurrahman Wahid}

Abdurrahman Wahid's presidential term was relatively short. It was only two years, from October 1999 to July 2001. Wahid was ousted following the case of funds of

\footnotetext{
13 Ni'matul Huda, “Peningkatan Peran Wakil Presiden Melalui Keppres No. 121 Tahun 2000”, Jurnal Hukum, Vol. 14, No. 7, 2000, p. 115.

$14 \quad$ Harun Al Rasyid, Pengisian Jabatan Presiden, op.cit., p. 104.
} 
the Employee Welfare Fund Foundation of the Indonesia Logistics Bureau (Bulog Badan Urusan Logistik) and the case of Brunei Darussalam Sultan's funds given to President Wahid. Therefore, the cases are known as Buloggate and Bruneigate. The case triggered 236 members of the House to propose the use of the inquiry right to investigate the two cases.

The House of Representatives approved the proposal. A Special Committee was conducted official investigation. In its report to the House's Plenary Meeting on January 5, 2001, the Special Committee concluded that in the Buloggate case, it was suspected that President Abdurrahman Wahid played a role in withdrawing and using Yanatera Bulog's funds. In Bruneigate case, President Abdurrahman Wahid's statements were inconsistent on the issue of the aid of the Sultan of Brunei Darussalam, showing that the President had conveyed untruthful information to the public. ${ }^{15}$

The Plenary Meeting accepted and approved the conclusions. The house followed up the Plenary Meeting by issuing the first referendum on February 1 , 2001, and second memorandum on May 1, 2001. Then, the House of Representatives proposed the People's Consultative Assembly to hold a Special Session requiring President Wahid to provide accountability since he did not respond the House's first and second memorandum. The Session presumed that the President had violated the National Guidelines of State Policy, Article 9 of the 1945 Constitution on the oath of office, and the Decree of the People's Consultative Assembly Number XI/MPR/1998 on the Clean and Free of Corruption, Collusion, and Nepotism State Organization. ${ }^{16}$

In advance of the Special Session, President Abdurrahman Wahid issued a controversial policy and considered law violations. Firstly, the President ousted Police General S. Bimantoro as the Chief of the Indonesian National Police, replacing him with General Commissioner Chaeruddin Ismail. This policy was considered a violation on Article 7 (3) of the Decree of the People's Consultative Assembly Number VI/MPR/2000. The Article requires dismissal and appointment of the Chief of the Indonesian National Police to gain approval from the House of Representatives. Secondly, President Wahid issued a decree dismissing the People's Consultative Assembly and the Golkar Party (Party of Functional Groups). ${ }^{17}$ In the aftermath, the People's Consultative Assembly dismissed President Wahid by issuing the Decree Number II/MPR/2001 on the Accountability of the President of Indonesia, K.H. Abdurrahman Wahid. The decree declares that the President has violated National Guidelines of State Policy due to his absence and refusal to

\footnotetext{
15 Dewan Perwakilan Rakyat Republik Indonesia, Dewan Perwakilan Rakyat Republik Indonesia dalam Proses Demokratisasi: Laporan Pelaksanaan, Fungsi, Tugas dan Wewenang DPR RI Pada Sidang Tahunan MPR RI Tahun kedua 2000-2001, Jakarta: DPR RI, 2001, p. 459. Ibid., p. 460.

17 Hamdan Zoelva, Impeachment Presiden: Alasan Tindak Pidana Pemberhentian Presiden Menurut UUD 1945, Jakarta: Konstitusi Press, 2005, p. 103.
} 
provide accountability report in the 2001 Special Session and the release of the Presidential Decree on July 23, 2001.

The legal basis of the succession of President Abdurrahman Wahid is provided in Article 2 of the Decree of the People's Consultative Assembly Number II/MPR/2001 as follows.

"Memberhentikan K.H. Abdurrahman Wahid sebagai Presiden Republik Indonesia dan mencabut serta menyatakan tidak berlaku lagi Ketetapan Majelis Permusyawaratan Rakyat Republik Indonesia Nomor VII/MPR/1999 tentang Pengangkatan Presiden Republik Indonesia".

[to dismiss K.H. Abdurrahman Wahid as the President of the Republic of Indonesia and to revoke the Decree of the People's Consultative Assembly of the Republic of Indonesia Number VII/MPR/1999 on the Appointment of the President of the Republic of Indonesia].

Based on the Article 2 above, President Wahid was 'dismissed' from his office. In accordance with Article 8 of the 1945 Constitution, reasons of succession are decease, resignation, and incapability to carry out his/her obligations. There is no word referring to dismissal in Article 8 of the 1945 Constitution. The constitutional law experts have debated it. For instance, Al Rasyid states that 'resign' cannot be interpreted as 'being dismissed'. Being dismissed means "by the wishes of other parties."18 In contrast, Asshiddiqie explains that in the formulation of the original Article 8 , the words referring to 'resign' and 'being dismissed' have no difference. The word berhenti (resign) in the Article includes three meanings: (1) resigning due to unilateral resignation; (2) resigning by request or resignation application, and (3) resigning due to dismissal. ${ }^{19}$

Asshiddiqie further mentions that there was an increase of the House's political roles and the decrease of the President's role in the dismissal of Abdurrahman Wahid. For the evidence, the People's Consultative Assembly appointed Abdurrahman Wahid democratically, but Wahid failed because of the Buloggate that was created through political discourse wherein the juridical truth was not completely examined. The phenomenon, according to some politicians, becomes an important factor that encourages politicians to protect president from unpopular parliamentary movement. ${ }^{20}$

Harun Al Rasyid, Pengisian Jabatan Presiden, op.cit., p. 97.

Jimly Asshiddiqie, Konsolidasi Naskah UUD 1945 Setelah Perubahan Keempat, Jakarta: Yarsif Watampone, 2013, p. 19.

20 Jimly Asshiddiqie, "Pemilihan Langsung Presiden dan Wakil Presiden", Jurnal Unisia, Vol. 51, No. 1, 2011, p. 11. 
The dismissal of President Wahid by the People's Consultative Assembly inspired the Third Amendment to the 1945 Constitution, Article 8 paragraph (1). The article now has an addition referring to "being dismissed" as follows.

"Jika Presiden mangkat, berhenti, diberhentikan, atau tidak dapat melakukan kewajibannya dalam masa jabatannya, ia digantikan oleh Wakil Presiden sampai habis masa jabatannya".

[If President is decease, resigns, is dismissed, or cannot conform to his/her obligations within the term of office, Vice President shall succeed him/her until the end of the term of office.]

The provision explicitly regulates legal mechanism in the process of dismissing president and/ or vice president. It is intended to make the mechanism not merely be based on political reasons. The mechanism begins with political process in the House of Representatives. It continues to legal proceedings in the Constitutional Court to examine, to hear, and to decide the House's opinion that president and/or vice president have committed betrayal against the state, corruption, bribery, other serious crimes, disgraceful acts, or no longer be in conformity with the requirements. Then, it is continued to political process in the People's Consultative Assembly. These mechanisms are regulated in Articles 7A and 7B of the Third Amendment to the 1945 Constitution.

The presence of the Constitutional Court in the process of dismissing president signifies legal process in addition to political process, which has been the domain of political institutions (the People's Consultative Assembly and the House of Representatives). There must be legal reasons that are examined by the Constitutional Court. At the present, the mechanism and the reasons behind a dismissal are more complicated. It is intended to strengthen the presidential system and to reinforce constitutional and democratic state principles. However, in the constitutional practice, there is no dismissal process using the mechanism stated in Articles 7A and 7B.

After Wahid's impeachment, Megawati Soekarno Putri was appointed President until the end of the term of office. Hamzah Haz was appointed the Vice President. In this context, the vice-presidential succession is in line with Article 8 of the 1945 Constitution. The vacant office of vice president is referred by Article 8 (2) and (3) of the Third Amendment to the 1945 Constitution. The article provides a sixty-day deadline for the appointment of vice president and thirty-day deadline for the simultaneous vacant offices of president and vice president. The arrangement shows that the offices of president and vice president should not be vacant, considering the importance of both positions in day-by-day government's administration. 


\section{Impeachment of the President}

Impeachment is derived from the word 'impeach', which means to accuse, to charge, to suspect, to summon for providing accountability. ${ }^{21}$ The Black's Law Dictionary defines impeachment as "a criminal proceeding against a public officer, before a quasi-political court, instituted by a written accusation called 'articles of Impeachment". ${ }^{22}$ Impeachment in English is synonymous with the word accuse or charge. Therefore, impeachment does not equal to termination, dismissal, or deposal before the term of office ends because impeachment does not always have to end with dismissal of president.

In Indonesia, state officials that could be impeached are only president and vice president. It is different from the United States' system where it is not only president and vice president but also some high-rank state officials. As an example, Andrew Johnson was charged with the violation of the oath of office and misconduct but, in the aftermath, President Johnson was not dismissed. In a Senate's voting, Johnson was saved. ${ }^{23}$ In addition, Nixon's Watergate scandal led to an impeachment. However, the process was not completed since Nixon resigned from his office. Later on, he was recorded as the first president who resigned under impeachment pressure. ${ }^{24}$

Afterwards, in the case of William Jefferson Clinton, known as Monica Lewinsky affair scandal, the reasons are perjury and obstruction of justice. The House approved the impeachment of President Clinton. The impeachment process ended in the Senate. The Senate saved Clinton by absolute vote. He remained in the office of president. ${ }^{25}$ In South Korea, Prime Minister Roh Moo-hyun was charged of bribery in the general election he won. Parliament states that Roh Moo-hyun was proven guilty and dismissed from his office. Then, Roh Moo-hyun brought his case to the Constitutional Court. In the decision, Roh Moo-hyun did the bribery indeed but it was not enough to dismiss him from the office of Prime Minister. ${ }^{26}$

Since the office of President was established in 1945, seven persons have served as president of Indonesia. They are Sukarno, Suharto, Habibie, Abdurrahman Wahid, Megawati Soekarnoputri, Susilo Bambang Yudhoyono, and Joko Widodo. Of the seven presidents, four of them were ousted from the office before the end of the term, excluding Megawati Soekarnoputri, Susilo Bambang Yudhoyono, and Joko Widodo. The more dominant factors of the dismissals are political reasons rather than legal reasons. This is due to the procedures of

21 John M. Echols and Hassan Shadily, Kamus Inggris Indonesia: An English-Indonesian Dictionary, $25^{\text {th }}$ ed., Jakarta: Gramedia Pustaka Utama, 2000, p. 312.

22 Henry Campbell, Black's Law Dictionary: Definitions of term and Phrase of American and English Jurisprudence, Ancient and modern, St.Paul, Minn: West Group, 1991, p. 516.

23 Achmad Roestandi, Mahkamah Konstitusi Dalam Tanya Jawab, Jakarta: Sekretariat Jenderal dan Kepaniteraan Mahkamah Konstitusi RI, 2006, p. 171.

Winarno Yudho. et al, op.cit., p. 39.

Achmad Roestandi, op.cit., p. 171.

Ibid., p. 172. 
the dismissal in Article 8 of the pre-amended 1945 Constitution that was multiinterpretation and did not specify the mechanism and the reasons of the dismissal.

The amended 1945 Constitution set the reasons and mechanisms of president dismissal more firmly. Article 7A of the 1945 Constitution reads as follows.

"The President and/or the Vice-President may be dismissed from his/her position during his/her term of office by the People's Consultative Assembly on the proposal of the House of Representatives, both if it is proven that he/she has violated the law through an act of treason, corruption, bribery, or other act of a grave criminal nature, or through moral turpitude, and/or that the President and/or Vice-President no longer meets the qualifications to serve as President and/or Vice-President."

Based on the provision, there are two valid reasons of dismissal. The first is the violation on the law through an act of treason, corruption, bribery, or other act of a grave criminal nature, or through moral turpitude (despicable deeds). Two of the five types of law violations are multi interpretations. They are other act of a grave criminal nature, or through moral turpitude (despicable deeds). The Constitutional Court Law states that other act of a grave criminal nature are criminal offenses that are punishable by imprisonment for five years or more and moral turpitude, or also known as despicable deeds, are acts that can demean president and/or vice president. Despicable deeds can be interpreted as acts that are in the contrary to religious norms, moral norms, and customary norms such as public drunk, gambling, drug addicts, and adultery. It is very difficult to determine the criteria for despicable deeds since all forms of criminal offenses are despicable. Thus, the formulation of other serious criminal offenses and despicable deeds are still general, not yet well-defined. Therefore, an additional regulation is needed in the form of a law. The second is no longer meets the qualifications to serve as President and/or Vice-President. It refers to the conditions as specified in Article 6 (1) of the 1945 Constitution, which are (1) citizen of Indonesia since birth, (2) never have acquired another citizenship by his/her own will, (3) never have committed an act of treason against the State, and (4) mentally and physically capable of implementing the duties and obligations of President or Vice-President.

Article 7B of the 1945 Constitution regulates the mechanism of dismissal. First, proposal may be submitted by the House of Representatives to the People's Consultative Assembly by first submitting a request to the Constitutional Court to investigate, bring to trial, and issue a decision on the opinion of the House either that the President and/or Vice-President has violated the law mentioned in Article 7A of the 1945 Constitution. The submission of the request of the House of Representatives to the Constitutional Court shall only be made with the support of at least 2/3 of the total members of the House of Representatives who are present 
in a plenary session that is attended by at least $2 / 3$ of the total membership of the House of Representatives.

Second, the House of Representatives shall submit a written application that clearly describes the alleged violation of law committed by the President to the Constitutional Court. The written application shall attach verdict and decisionmaking process in the House of Representatives; summary and/or minutes of meetings in the House of Representatives accompanied by evidence regarding alleged violations committed by the President; the deadline for completing applications that must be decided by the Constitutional Court is within 90 days. The forms of verdicts issued by the Constitutional Court can be unacceptable, rejected, justifying the opinion of the DPR. In the process of examining the petition of the House of Representatives, the Constitutional Court shall be required to call the President as the litigant to provide information or to ask the President to provide written information. If the President and/or Vice President resign during the examination process in the Constitutional Court, the examination process shall be stopped, and the application is declared null and void.

Third, the People Consultative Assembly shall hold a Plenary Session following the proposal of the House of Representatives, based on the verdict of the Constitutional Court to confirm the House's opinion, no later than 30 days after the Assembly accepted the proposal. The President and the Vice President must be present to give information at the Assembly's Plenary Session, which shall be attended by at least $3 / 4$ of the number of Members of the Assembly and is approved by at least $2 / 3$ of the total number of present members.

The provisions of Article 7B of the 1945 Constitution can result three possibilities. First, the Constitutional Court refuses or do not accept the opinion/proposal of the House on impeachment. Accordingly, the impeachment process cannot be proceeded to the Special Session of the People Consultative Assembly. Second, the Constitutional Court confirms the opinion or proposal of the House on impeachment. Therefore, the People Consultative Assembly shall hold a Special Session to dismiss the president. Third, the Constitutional Court accepts the House's opinion or proposal on impeachment but the Special Session of the People Consultative Assembly does not dismiss the president. ${ }^{27}$ The third possibility has raised debates since the Constitutional Court approves the House's opinion but the People Consultative Assembly may decide against the Constitutional Court's opinion. The focus lies on the authority to dismiss the president, whether the three institutions shall make the same decision.

The amended 1945 Constitution and subsidiary laws do not regulate the juridical implications of the Constitutional Court's decision on the issue of impeachment. Marzuki, a Constitutional Judge, argues that decree of the People Consultative Assembly may counter to dismiss the president and/or the vice-

27 Maruarar Siahaan, Hukum Acara Mahkamah Konstitusi, Jakarta: Konstitusi Press, 2005, p. 79. 
president despite the fact that the Constitutional Court may previously validate the House's opinion. It does not mean that political decision put aside law verdict but dismissal of president and/or vice-president is an authority of the People's Consultative Assembly, not any judicial institutions. ${ }^{28}$ Harjono states the similar opinion that the court's obligation in a dismissal of president and/or vice president is actually more related to criminal justice, not state administrative justice. Dismissal process should not be delegated to the Constitutional Court but to the Supreme Court. The Supreme Court has criminal judges and criminal procedural law. ${ }^{29}$

On the other hand, the problem lies around decree of the Constitutional Court, which may or may not justify the House's. The decree does not bind legally so that the People Consultative Assembly may ignore the Constitutional Court's legal decision. If at all possible, the mechanism of impeachment shall begin with the political process through the House of Representatives and the People Consultative Assembly and shall end with legal process involving the Constitutional Court. However, at least Articles 7A and 7B of the 1945 Constitution are important milestone in the state's administration because the impeachment process is not only covering political process but also through legal process.

Impeachment mechanism after the amendment to the 1945 Constitution is better compared to the one before. Mahfud states that, previously, a Presidential impeachment in term of office was only based on political considerations as stipulated in the Decree of the People Consultative Assembly Number III/MPR/1978. It emphasized violations of the National Guidelines of State Policy that the interpretation is very broad. However, nowadays, a president can only be impeached for more specific reasons that must be proven legally through a privileged court of law. Here, the president may win votes in a democracy. It is combined, and even tested, with substance and legal procedures based on nomocracy. ${ }^{30}$

Privileged court of law is the concept of dismissing high-ranking state officials, including the president, through special legal proceedings. A president who is deemed to have violated the law is dismissed through an expedited judicial mechanism without going through the conventional court hearings from the lower levels. ${ }^{31}$ However, the practice has never happened. The matter may be solved after a case appearance so that it can become jurisprudence in the impeachment process.

\footnotetext{
28 M. Laica Marzuki, "Pemakzulan Presiden/Wakil Presiden Menurut Undang-Undang Dasar 1945", Jurnal Konstitusi, Vol. 7, No. 1, 2010, p. 26.

29 Harjono, Konstitusi sebagai Rumah Bangsa; Pemikiran Hukum Dr. Harjono, SH, MCL Wakil Ketua Mahkamah Konstitusi, Jakarta: Sekretariat Jenderal dan Kepaniteraan Mahkamah Konstitusi, 2008, p. 171.

30 Mohammad Mahfud MD., Perdebatan Hukum Tata Negara: Pasca Amandemen Konstitusi, Jakarta: LP3ES, 2007, p. xvi.

31 Denny Indrayana, Negara Antara Ada dan Tiada: Reformasi Hukum Ketatanegaraan, Jakarta: Kompas, 2008, p. 207.
} 


\section{Conclusion}

Prior to the amendment to the 1945 Constitution, the People's Consultative Assembly had an important role in presidential succession. The People's Consultative Assembly elected and appointed the president; and the Assembly was also responsible to request the president's accountability. The People's Consultative Assembly had the authority to perform succession and impeachment to the president based on its political preferences. In fact, the pre-amended 1945 Constitution does not regulate the authority of the Assembly to dismiss the president. The only regulation is Article 4 of the Decree of the People's Consultative Assembly Number III/MPR/1978 on the Position and the Work-Order Relationship of the Highest State Institution with/or Among State Higher Institutions. The prove is the successions of Soekarno, Soeharto, and Abdurrahman that ignored Article 8 of the 1945 Constitution and preferred to the majority opinion in the People's Consultative Assembly.

The 1945 Constitution describe reasons of the presidential succession. The first is decease. In this case, there are no presidential succession resulted by this reason. The second is resignation. The case happened in the succession of President Soeharto. The third is dismissal. The case happened in the succession of President Wahid. However, the regulation of dismissal prior to the amendment to the 1945 Constitution was in existed. The word that refers to "being dismissed" is added after the amendment. The fourth is incapability to carry out obligations. The reason is for the succession of President Soekarno. After all, the practices of presidential successions show that political considerations are more dominant than legal considerations.

On the other hand, the implementation of Article 8 of the 1945 Constitution was has been inconsistent. For instance, during the term of President Soekarno, the office of vice president was left vacant after the resignation of Hatta on December 1, 1966. The position was vacant up until the appointment of Sri Sultan Hamengkubuwono IX as the vice president of President Soeharto on March 24, 1973. During the term of President Soeharto, there were only vice-presidential successions, not presidential succession of course. During Habibie's presidency, the office of vice president also remained vacant. Then, the term of office for the newly appointed president should be for the rest of the presidential term of office. However, the provision was not applied in the case of Habibie since he preferred to accelerate the General Election.

\section{References}

\section{Books}

Achmad Roestandi, Mahkamah Konstitusi Dalam Tanya Jawab, Sekretariat Jenderal dan Kepaniteraan Mahkamah Konstitusi Republik Indonesia, Jakarta, 2006.

Bagir Manan, Lembaga Kepresidenan, $2^{\text {nd }}$ ed., FH UII Press, Yogyakarta, 2003. 
Teori dan Politik Konstitusi, UII Press, Jakarta, 2003.

Campbell, Henry, Black's Law Dictionary: Definitions of term and Phrase of American and English Jurisprudence, Ancient and modern, West Group, St. Paul, Minn, 1991.

Denny Indrayana, Negara Antara Ada dan Tiada: Reformasi Hukum Ketatanegaraan, Kompas, Jakarta, 2008.

Dewan Perwakilan Rakyat Republik Indonesia, Dewan Perwakilan Rakyat Republik Indonesia dalam Proses Demokratisasi: Laporan Pelaksanaan, Fungsi, Tugas dan Wewenang DPR RI Pada Sidang Tahunan MPR RI Tahun kedua 2000-2001, DPR RI, Jakarta, 2001.

Echols, John M., and Hassan Shadily, Kamus Inggris Indonesia: An EnglishIndonesian Dictionary, $25^{\text {th }}$ ed., Gramedia Pustaka Utama, Jakarta, 2000.

Hamdan Zoelva, Impeachment Presiden: Alasan Tindak Pidana Pemberhentian Presiden Menurut UUD 1945, Konstitusi Press, Jakarta, 2005.

Harjono, Konstitusi sebagai Rumah Bangsa; Pemikiran Hukum Dr. Harjono, SH, MCL Wakil Ketua Mahkamah Konstitusi, Sekretariat Jenderal dan Kepaniteraan Mahkamah Konstitusi, Jakarta, 2008.

Harun Al Rasyid, Pemilihan Presiden dan Penggantian Presiden dalam Hukum Positif Indonesia, Fakultas Hukum Universitas Indonesia, Jakarta, 1995.

, Pengisian Jabatan Presiden, Pustaka Utama Grafiti, Jakarta, 1999.

Jimly Asshiddiqie, Konsolidasi Naskah UUD 1945 Setelah Perubahan Keempat, Yarsif Watampone, Jakarta, 2013.

Logeman, H. A, Tentang Teori Suatu Hukum Tata Negara Positif (Over de Theorie van Een Stelling Staatsrecht), translated by Makkatutu and J.C. Pangkerego, Ichtiar Baru Van Hoeve, Jakarta, 1975.

Maruarar Siahaan, Hukum Acara Mahkamah Konstitusi, Konstitusi Press, Jakarta, 2005.

Mohammad Mahfud MD., Membangun Politik Hukum, Menegakkan Konstitusi, Rajawali Press, Jakarta, 2010.

Perdebatan Hukum Tata Negara: Pasca Amandemen Konstitusi, LP3ES, Jakarta, 2007.

Muchyar Yara, Pengisian Jabatan Presiden dan Wakil Presiden di Indonesia: Suatu Tinjauan Sejarah Hukum Tata Negara, Nahdilah Ceria Indonesia, Jakarta, 1995.

Winarno Yudho, et.al, Seri Penelitian Ilmiah Mahkamah Konstitusi: Mekanisme Impeachment dan Hukum Acara Mahkamah Konstitusi, Pusat Penelitian dan Pengkajian Sekretariat Jenderal dan Kepaniteraan Mahkamah Konstitusi RI, Jakarta, 2005.

\section{Other Documents}

Jimly Asshiddiqie, "Pemilihan Langsung Presiden dan Wakil Presiden", Jurnal Unisia, Vol. 51, No. 1, 2011. 
M. Laica Marzuki, "Pemakzulan Presiden/Wakil Presiden Menurut Undang-Undang Dasar 1945", Jurnal Konstitusi, Vol. 7, No. 1, 2010.

Ni'matul Huda, "Peningkatan Peran Wakil Presiden Melalui Keppres No. 121 Tahun 2000", Jurnal Hukum, Vol. 14, No. 7, 2000.

Saldi Isra, "Pemilihan Presiden Langsung dan Problematik Koalisi Dalam Sistem Presidensial", Jurnal Konstitusi, Vol. 2, No. 1, 2009.

\section{Legal Documents}

1945 Constitution of the Republic of Indonesia.

Decree of the Provisional People's Consultative Assembly Number XV/MPRS/1966 on the Election or the Appointment of The Vice President and the Procedures on the Appointment of the Office of President [Ketetapan MPRS Nomor XV/MPRS/1966 Tahun 1966 tentang Pemilihan/Penunjukkan Wakil Presiden Dan Tata-Cara Pengangkatan Pejabat Presiden].

Decree of the Provisional People's Consultative Assembly Number XXXIII/MPRS/1967 on the termination of Soekarno's Presidency [Ketetapan MPRS Nomor XXXIII/MPRS/1967 Tahun 1967 tentang Pencabutan Kekuasaan Pemerintahan Negara Dari Presiden Sukarno].

Decree of the People's Consultative Assembly Number VII/MPR/1973 on the Situation of Incapability of President and/or Vice President of the Republic of Indonesia [Ketetapan Majelis Permusyawaratan Rakyat Nomor VII/MPR/1973 Tahun 1973 tentang Keadaan Presiden dan/atau Wakil Presiden Republik Indonesia Berhalangan].

Decree of the People's Consultative Assembly Number III/MPR/1978 on the Position and the Work-Order Relationship of the Highest State Institution with/or Among State Higher Institutions [Ketetapan MPR Nomor III/MPR/1978 Tahun 1978 tentang Kedudukan dan Hubungan Tata-Kerja Lembaga Tertinggi Negara dengan/atau Antar Lembaga-Lembaga Tinggi Negara].

Decree of the People's Consultative Assembly Number XI/MPR/1998 on the Clean and Free of Corruption, Collusion, and Nepotism State Organization [Ketetapan MPR RI Nomor XI/MPR/1998 tentang Penyelenggara Negara yang Bersih dan Bebas dari Korupsi, Kolusi, dan Nepotisme].

MPR Decree No. VI/MPR/2000 concerning the Separation of Indonesian National Army and State Police of the Republic of Indonesia [Ketetapan MPR Nomor VI/MPR/2000 Tahun 2000 tentang Pemisahan Tentara Nasional Indonesia dan Kepolisian Negara Republik Indonesia].

Decree of the People's Consultative Assembly Number II/MPR/2001 on the Accountability of the President of Indonesia, K.H. Abdurrahman Wahid [Ketetapan MPR No II/MPR/2001 tentang Pertanggungjawaban Presiden RI KH Abdurrahman Wahid]. 